4 Kizito Nishimwe ${ }^{1, *}$, Immaculate Wanjuki ${ }^{2}$, Charles Karangwa ${ }^{3}$, Ross Darnell ${ }^{4}$ and Jagger 5 Harvey $^{5,2,6}$

\section{An initial characterization of aflatoxin B1 contamination of maize sold in the principal retail markets of Kigali, Rwanda}

1: School of Food Sciences and Technology - College of Agriculture, Animal Sciences and Veterinary Medicine - University of Rwanda, Po. Box: 3971 Kigali, Rwanda

2: Biosciences eastern and central Africa - International Livestock Research Institute (BecA ILRI) Hub, Nairobi 00100, Kenya

3: School of Medicine and Pharmacy - College of Medicine and Health Sciences - University of Rwanda, Po. Box: 3286 Kigali, Rwanda

4: Commonwealth Scientific and Industrial Research Organization (CSIRO), GPO Box 2583, Brisbane QLD 4001, Australia

5: Feed the Future Innovation Lab for the Reduction of Post-Harvest Loss, Kansas State University, Manhattan, Kansas, USA

6: Queensland Alliance for Agriculture and Food Innovation, University of Queensland, Australia

*Corresponding author: Email: knishimwe@ur.ac.rw, kizito.nishimwe@gmail.com

\section{Abstract}

Food security considerations have shifted in recent years, with the recognition that available food should also be nutritious and safe. There is a growing evidence base for contamination of maize and other crops by fungal toxins in the tropics and sub-tropics. As an initial snapshot of contamination by one of these toxins in Rwanda, Aflatoxin B1 (AFB1) was analyzed in 684 samples of maize flour collected in seven principal retail markets of Kigali and in 21 samples of animal feed from seven feed vendors. Two rounds of sample collections were carried out, the first in September 2014 and the second in January 2015. A questionnaire given to vendors was used to determine if gender and education level of vendors, origin of maize and awareness of aflatoxins had any significant effect on AFB1 level in collected samples. Enzyme-Linked Immunosorbent Assay (ELISA) and Immuno-affinity fluorimetery were used to analyze samples. 
Only markets had a significant effect on AFB1 level; for the two collections, differences were inconsistent among markets. In the first round, market means of AFB1 varied between 8.0 \pm 5.57 $\mu \mathrm{g} / \mathrm{kg}$ and $24.7 \pm 23.74 \mu \mathrm{g} / \mathrm{kg}$ and for the second round, between $10.4 \pm 8.4 \mu \mathrm{g} / \mathrm{kg}$ and $25.7 \pm 25.85$ $\mu \mathrm{g} / \mathrm{kg}$. In most animal feed samples AFB1 was $>100 \mu \mathrm{g} / \mathrm{kg}$. None of the vendors interviewed was aware of the risk of mycotoxin contamination in their maize-based flours and feed. Limits set by the United States Food and Drug Administration $(20 \mu \mathrm{g} / \mathrm{kg})$ for total aflatoxins and European Commission ( $2 \mu \mathrm{g} / \mathrm{kg}$ ) for AFB1 for maize flour imports, were varied between 2-35\% and $66-100 \%$ of samples, respectively. The implications of this study for human and animal health in Rwanda suggest that expanded surveys are needed to understand the scope of contamination, given the influence of environment and other factors on aflatoxin accumulation. Available options to mitigate and monitor aflatoxin contamination can be further deployed to reduce contamination.

Key words: Aflatoxin B1, Awareness, Kigali, Maize, Market, Rwanda

\section{Introduction}

The Government of Rwanda through its Economic Development and Poverty Reduction Strategy (EDPRS) has used crop intensification programs (Minecofin, 2014) to triple maize production from 144,481 tons (t) in 2008 to 573,038 t in 2013 (NISR, 2014). However, to the best of our knowledge, there is no published record of the amount of stored maize in Rwanda that is potentially contaminated by aflatoxigenic fungi or by aflatoxin. Such contamination is a common problem in much of sub-Saharan Africa and globally, and has implications for human and animal health, as well as international trade (Wagacha \& Muthomi, 2008). Aspergillus flavus and A. parasiticus are the major species responsible for aflatoxin production, with other Aspergillus species such as A. nomius and A. arachidicola also capable of its production (Perrone, Gallo, \& Logrieco, 2014). As yet, toxigenic species and aflatoxins have yet to be characterized and reported in Rwanda. 
62 There are four naturally occurring aflatoxins (AFs) viz AFB1, AFB2, AFG1 and AFG2 63 (D’Mello, Placinta \& Macdonald 1999; Pitt, 2014); AFM1, a metabolite of AFB1, is also found 64 in dairy products (Prandini et al., 2009). Of the types, AFB1 has been reported to be the most 65 dangerous mutagen and carcinogen (Francis et al.,1989; Anitha et al. 2014; Doi and Uetsuka 66 2014; IARC, 2015), and where aflatoxins are present in foods, generally exceeds half the total 67 amount present (Matumba et al., 2014). For these reasons, regulatory limits for aflatoxins include 68 AFB1, and a number of analytical methods have been developed to measure its concentration or 69 that of total aflatoxins (Matumba et al., 2014).

70 Given the scope of contamination reported, aflatoxins currently pose serious health problems in 71 many parts of Africa (Wagacha \& Muthomi 2008; Gnonlonfin et al 2013; Probst, 72 Bandyopadhyay \& Cotty 2014) and other parts of the tropics and sub-tropics. For example, an 73 aflatoxicosis outbreak in Kenya in 2004 caused 125 deaths (Lewis et al., 2005). Chronic dietary 74 exposure to aflatoxins is common in the east African region (Ismail, Taligoola, \& Ssebukyu, 75 2004, Ek, Ka, \& Kang, 2009; Owaga, Muga, Mumbo, \& Aila, 2011; Rushunju, Laswai, Ngowi, 76 \& Katalambula, 2013) and in some cases, this is associated with the development of tumors 77 (Peers \& Linsell 1973; Awadelkarim, Mariani-Costantini, \& Elwali 2012; Elzupir \& Alamer, 78 2014). Stunting levels in the region are also high by comparison globally, and aflatoxin exposure 79 has been associated with stunting (Asiki et al., 2014; IARC, 2015; Lombard, 2014).

80

81

82

83

84

85

86

87

88

89

90

91

The dearth of information for Rwanda on levels of contamination of maize by fungi and their toxins is possibly associated with a lack of appreciation of the current risks of exposure (Zain, 2011) and the factors that contribute to exposure to those risks. Aside from biophysical factors themselves (e.g., pre-, peri- and post-harvest practices, crop species and genotype, fungal populations, climatic conditions), three other factors have been previously reported to significantly influence levels of aflatoxins in food commodities: levels of education and awareness, and gender. Jolly et al. (2006) noted that Ghanaian participants in their study with primary education only or less were 2.3 times more likely to have AFB1 albumin-adduct (AFB1 that is covalently bound in peripheral blood albumin) in their blood than those with secondary education. Another study found that women were more concerned with creating an awareness of the risks of AFs and the benefit of reducing their levels whereas men were most concerned about the cost of reducing AF levels (Jolly, Bayard, Awuah, Fialor, \& Williams, 2009). Low level of 
92 knowledge on fungal and AF contamination has been found to be positively correlated with high

93 levels of AFs in the population by Sabran et al. (2012) .

94 In the absence of published data on the prevalence of aflatoxins in Rwanda, the first objective of 95 this study was undertaken to determine the contamination levels of AFB1 in maize sold in 96 markets in Kigali. The second objective was to establish whether there was any association

97 between AFB1 levels in maize flour intended for human consumption and animal feeds, and the 98 gender and education level of vendors, the origin of the maize, and awareness of AFs and other 99 mycotoxins. Concentrations of AFB1 obtained were compared to published maximum allowable 100 limits for human and animal consumption. Characterizing the scope of contamination, and 101 understanding potential social drivers of risk can help inform strategic and effective piloting and 102 scaling of interventions to mitigate this challenge in Rwanda.

103

104 105

106 107 108 109 110 111

\section{Materials and methods}

\subsection{Sampling}

\subsubsection{Sampling maize intended for human consumption}

Sample collections from Kigali markets were carried out in September 2014 (Round I) and January 2015 (Round II). A total of 474 samples from 158 vendors and 210 samples from 70 vendors were collected randomly in the first and second round, respectively. Seven principal retail markets (Nyamirambo, Kimisagara, Gikondo, Kimironko, Kicukiro, Nyarugenge and Nyabugogo) located in three districts (Kigali, Gasabo, Kicukiro and Nyarugenge) were selected. As they are open markets, vendors both inside and outside the formal market buildings were considered.

From each vendor, three $1 \mathrm{~kg}$ samples of maize flour were collected from each of three randomly selected bags. Because of the likelihood of a heterogeneous fungal and toxin distribution in each bag (Campbell, Whitaker, Pohland, Dickens, \& Park, 1986), each sample consisted of ten $100 \mathrm{~g}$ sub-samples collected from different parts of the bag. Each $1 \mathrm{~kg}$ sample was thoroughly mixed and a $100 \mathrm{~g}$ sub-sample used for analysis. In Round I, a questionnaire was used to record the gender and education level of each vendor (primary only or primary and secondary education), the origin of the maize (domestic or imported) and any awareness by the vendor of aflatoxins and other mycotoxins. Round II collections were undertaken to verify whether market differences 
121 identified in Round I were a repeatable phenomenon attributable to specific markets. For Round 122 II, ten maize flour vendors were randomly selected from each of the seven markets. Samples were collected as for the Round I but only the origin of maize was recorded.

\subsubsection{Sampling for maize intended for animal feed}

125

126

127

128

129

130

131

132

133

134

135

136

137

138

139

140

141

142

143

144

145

146

147

Three animal feed vendors were selected in Nyarugenge District, two in Kicukiro District and two in Gasabo District which yielded 11, five and four samples respectively. The same methodology described above was used to gather the samples. The limited number of samples was because there were relatively fewer feed vendors. These animal feed samples were maizebased but contained groundnut and other ingredients.

\subsection{AFB1 analysis}

All samples were first analyzed using the competitive Enzyme-Linked Immunosorbent Assay (ELISA) technique (Catalog \# 941BAFL01B1-96, Helica Biosystems, Santa Ana, CA, USA) which allows quantification between 1.0-20.0 and 5.0-100 $\mu \mathrm{g} / \mathrm{kg}$ AFB1 with a 5 and 25 dilution factor respectively. Samples with AFB1 >100 $\mu \mathrm{g} / \mathrm{kg}$ were analyzed using immuno-affinity column fluorometry with a VICAM® fluorometer (Series-4EX, Source Scientific LLC, USA) which enables quantification between 2.0 - $300 \mu \mathrm{g} / \mathrm{kg}$ AFB1. For this study, maize intended for human consumption only required the ELISA method (AFB1 $<100 \mu \mathrm{g} / \mathrm{kg}$ ); however for animal feeds, most samples had AFB1 >100 $\mu \mathrm{g} / \mathrm{kg}$.

\subsubsection{ELISA}

The aforementioned AFB1 ELISA Quantitative Kit was used. Either $5.0 \mathrm{~g}$ (5× dilutions) or $1.0 \mathrm{~g}$ (25x dilution) of the maize flour sample was mixed with $25 \mathrm{ml}$ methanol (Sigma-Aldrich St. Louis, MO, USA):water (Milli-Q Water Purifier, Millipore, Bedford, MA, USA) (7:3 v/v) for 5 min at high speed (250 rpm) in a shaker (New Brunswick Scientific, Edison, NJ, USA). All standards and sample extracts were analyzed in duplicate micro-wells, according to manufacturer instructions. The micro-wells were measured optically by a micro-plate reader with an absorbance filter of optical density $450 \mathrm{~nm}$. A logit regression equation generated from standard ODs and corresponding standard concentrations was used to calculate the AFB1 concentration in 
sample extracts. The final concentration was adjusted according to the dilution factor; the limit of detection was $1.0 \mu \mathrm{g} / \mathrm{kg}$ and $5.0 \mu \mathrm{g} / \mathrm{kg}$ for the $5 \times$ and $25 \times$ dilutions, respectively.

a.) Method validation

Prior to sample analysis by ELISA, the method was validated for ensuring data quality. Spike recoveries and the Coefficient of Variation (CV) were calculated for each AFB1 standard concentration used respectively $(0,0.20,0.50,1,2$ and $4 \mu \mathrm{g} / \mathrm{kg})$ with the acceptable level of CV set at $5 \%$. Certified corn reference material obtained from the Office of the Texas State Chemist (OTC) were used to assess the accuracy of aflatoxin prediction.

b.) Quality control

In-house analytical method performance characteristics developed for assessing the accuracy, precision and linearity for each ELISA plate were performed to screen for the integrity of data generated. The linearity of calibration curve was assessed by calculating the regression coefficient $\left(r^{2}\right)$. The minimum acceptable level for the $r^{2}$ was set at 0.98 . The accuracy of the method was assessed in each ELISA plate by using three different known concentrations of certified ground corn samples of aflatoxins (OTC-Aflatoxin Proficiency Testing in Eastern and Central Africa program) for varying sample dilutions and quantification ranges. The three concentrations used are $5 \mu \mathrm{g} / \mathrm{kg}(+/-40 \%), 40 \mu \mathrm{g} / \mathrm{kg}(+/-34 \%)$ and $273 \mu \mathrm{g} / \mathrm{kg}(+/-20 \%)$. ELISA plates whose determined aflatoxin concentration of the reference material was off the range were repeated. One sample was randomly selected and analyzed twice per plate, and plates with greater than $10 \%$ relative percent difference were repeated.

\subsubsection{Immuno-affinity fluorometery}

Extracts were obtained by mixing $5.0 \mathrm{~g}$ sample with $0.5 \mathrm{~g}$ salt $(\mathrm{NaCl})$ and $25.0 \mathrm{ml}$ methanol:water $(8: 2 ; \mathrm{v} / \mathrm{v})$ and shaking the mixture for $5 \mathrm{~min}$ at $250 \mathrm{rpm}$ before filtering the extract (Catalog No 1001125 Filter Paper, 125 mm Ø, Whatman®, GE Healthcare UK Ltd, Buckinghamshire, UK). Subsequently, $2.0 \mathrm{ml}$ filtered extract was diluted with $8.0 \mathrm{ml}$ distilled 
water. The diluted extract was then filtered through a $1.5 \mu \mathrm{m}$ glass micro-fiber filter (VICAM, Sweden); $2.0 \mathrm{ml}$ of filtered diluted extract was then passed completely through an AflaTest® column at a rate of 1-2 drops $\mathrm{s}^{-1}$. Columns were washed twice with $5.0 \mathrm{ml}$ distilled and deionized water $\left(\mathrm{ddH}_{2} \mathrm{O}\right)$. The aflatoxin elution was completed by passing $1.0 \mathrm{ml}$ HPLC grade absolute methanol through the column and eluate collected into a glass cuvette. The latter was mixed with $0.5 \mathrm{ml}$ HPLC grade absolute methanol (Sigma-Aldrich, Switzerland). Then $1.0 \mathrm{ml}$ Aflatest developer was mixed by vortexing with the eluate. After $60 \mathrm{~s}$, total aflatoxin (AFB1 + AFB2 + AFG1 + AFG2) $(\mu \mathrm{g} / \mathrm{kg})$ concentration was read on a VICAM $®$ fluorometer calibrated using mycotoxin standards supplied by the manufacturer. The final concentration was adjusted for sample dilution..

\subsection{Statistical analysis}

AFB1 concentrations in different samples and associated socio-demographic factors collected during interview with vendors were entered into SPSS (IBM, PASW Statistics 16.0, USA) and analyzed with R software. The analysis was performed on the log transformed level of aflatoxin to reduce the heterogeneity in the variances among markets and rounds and skewness of the distribution among samples (Campbell et al., 1986; Maestroni \& Cannavan, 2011). A linear mixed model was used to calculate the association between the socio-demographic factors considered (gender of vendor, market origin of maize and awareness of aflatoxins) and the level of AFB1in samples using Analysis of Variance (ANOVA). Since socio-demographic data was collected for Round 1 only, analysis these terms could only be tested for Round 1 data. The chisquare test was applied to calculate the association between markets and two rounds of maize collection using the Analysis of Deviance (ANDEV). Mean, standard deviation and median were calculated for samples according to the markets. No p-values are associated with the ANOVA because of the ambiguity of the definition of the degrees of degrees of freedom ( $\mathrm{df}$ ) for the $\mathrm{F}$ distribution of each of the variables investigated; however since the number of samples was in the hundreds, 100 was used for the denominator. The Sums Squares (SS) was used to determine which components contribute most to the variance in aflatoxin levels.

AFB1 concentrations obtained were compared to different multiple maximum allowable limits set by different countries and organizations, and the percentage of maize samples above these limits was estimated. The European Commission (EC) has fixed the maximum levels for AFB1 
and total aflatoxins at $2 \mu \mathrm{g} / \mathrm{kg}$ and $4 \mu \mathrm{g} / \mathrm{kg}$ in maize, respectively (EC, 2006). In maize that is intended for human consumption, $10 \mu \mathrm{g} / \mathrm{kg}$ is the maximum level of total aflatoxins allowed by the Kenyan Government and the United Nations World Food Programme (WFP) (IFPRI, 2011), and $20 \mu \mathrm{g} / \mathrm{kg}$ by the Food and Drug Administration (FDA, United States of America) (Zain, 2011). For animal feed, $100 \mu \mathrm{g} / \mathrm{kg}$ total aflatoxins is currently the regulatory limit set by the FDA for corn and peanut products intended for breeding beef cattle, breeding swine or mature poultry (e.g. laying hens) (FDA, 2016).

\section{Results}

3.1 Markets

There were significant differences in AFB1 levels between markets in Round I with a >95\% contribution to the overall variation (Table 1). However there was also a significant interaction between Rounds (Table 2), indicating that the differences between markets were not the same in each Round. In Round I, the highest mean level, $24.7 \pm 23.7 \mu \mathrm{g} / \mathrm{kg}$, was found at Nyarugenge and the lowest, $8.0 \pm 5.6 \mu \mathrm{g} / \mathrm{kg}$ at Kimisagara; in Round II, the highest mean level, $25.7 \pm 25.9$ $\mu \mathrm{g} / \mathrm{kg}$, was found at Nyamirambo, and the lowest, $10.2 \pm 8.4 \mu \mathrm{g} / \mathrm{kg}$, at Nyarugenge (Table 3). Maximum levels did not exceed $98.6 \mu \mathrm{g} / \mathrm{kg}$ and $116.9 \mu \mathrm{g} / \mathrm{kg}$ for the Round I and Round II respectively.

\subsection{Socioeconomic factors, origin of flour and vendor awareness}

There was no discernable effect of gender, level of education or origin of flour on AFB1 level (Table 1; Figure 1a, b, c). The only imported maize flour encountered during sample collection was from Uganda, of which 100 samples were collected. All vendors stated that they were unaware that their maize flour may be contaminated with either aflatoxins or other mycotoxins. Mean levels of AFB1 for all three variables was approximately 8-10 $\mu \mathrm{g} / \mathrm{kg}$.

\subsection{Animal feed}

There were no differences in levels of AFB1 between markets located in three different districts (Figure 2). Mean levels varied between 100.4 and $168.6 \mu \mathrm{g} / \mathrm{kg}$, and maximum levels were 265 $\mu \mathrm{g} / \mathrm{kg}$.

\subsection{Proportion of maize flour samples above legal limits}


233 For all samples intended for human food consumption, the percentage range above each limit 234 considered vary between $66-100 \%, 28-87 \%$ and $2-35 \%$ for EU (2 $\mu \mathrm{g} / \mathrm{kg})$, Kenya-WFP (10 $235 \mu \mathrm{g} / \mathrm{kg}$ ) and USA FDA (20 $\mu \mathrm{g} / \mathrm{kg}$ ) limits, respectively (Table 4). For samples for animal feed, $23675 \%$ had $>100 \mu \mathrm{g} / \mathrm{kg}$ AFB1, the FDA limit.

237

238

239

240

241

242

243

244

245

246

247

248

249

250

251

252

253

254

255

256

257

258

259

260

261

\section{Discussion}

Contamination of samples collected in Kigali markets commonly exceeded legal limits, and there was a lack of awareness amongst vendors that their maize flours as they had never heard of aflatoxins. The factors that may be contributing to the current situation in Rwanda form the basis of this discussion.

Although there were significant differences in AFB1 levels between markets, there was no consistent pattern in the two Rounds of sampling. That the maize flour of domestic origin was contaminated was anticipated because although Rwanda experiences a montane and therefore less humid tropical climate than is often the case in other maize-growing parts of sub-Saharan Africa, it remains favorable for aflatoxigenic fungi growth (Clay \& Dejaegher, 1987, Medina, Rodriguez \&Naresh, 2014). However, similar levels of contamination were found in samples indicated by vendors of having originated from Uganda. Their precise origin remains unknown, although only small differences have been found in levels of aflatoxins in maize kernels collected from humid and dry zones in Uganda in one study (Kaaya and Kyamuhangire, 2006). However, the levels of AFB1 observed in Kigali markets were lower than those found during recognized outbreaks elsewhere, such as in Kenya (reported levels can exceed $1000 \mu \mathrm{g} / \mathrm{kg}$ ) (Lewis et al., 2005; Mwihia et al., 2008; Ndung et al., 2013; Mutiga et al., 2014). Pre- and postharvest conditions, including storage, play major roles in aflatoxin production, and how this affected the samples collected in this study is unknown.

There were no discernable effects of any of the socioeconomic factors tested. This may be linked to the limited time and the conditions under which vendors store the maize flour before it is sold having a minimal effect on levels of aflatoxins compared to the opportunities for contamination to develop during on-farm storage after harvest (Kaaya \& Kyamuhangire, 2006; Villers, 2014). All vendors had a basic formal education, and in Kigali, the minimum requirement before starting any business is to be literate. In contrast, levels of education in rural areas of Rwanda 
262 remain very low (Chatikobo, Manzi, Kagarama, Rwemarika \& Umunezero, 2009), and in spite 263 of technology transfer schemes for farmers (Odeyemi, 2003), their awareness of the dangers of 264 aflatoxin contamination is likely to be low. Kumar and Popat (2010) have shown that extension 265 staff and traders with basic levels of education can have a good understanding of concerns about 266 aflatoxin contamination.

267 However, vendors were unaware of mycotoxins and their consequences, a finding similar to that 268 for a groundnut value and supply chain in Malawi where awareness of aflatoxins was low 269 amongst all value-chain actors (Matumba, Van Poucke, Monjerezi, Ediage \& De Saeger, 2015). 270 An awareness amongst farmers has been shown to reduce the level of aflatoxins in maize 271 through good agricultural practices and proper handling (Muthomi, Mureithi, Chemining, 272 Gathumbi, \& Mutit, 2012). That traders in Kigali markets had no knowledge of aflatoxins 273 suggests that creating an awareness and capacity to reduce levels in maize and other products is 274 275 276

277 278 urgently needed for a range of stakeholders in Rwanda. Of course, the ultimate objective of reducing aflatoxin accumulation pre- and post-harvest also requires farmer education and deployment of interventions with actors across the value chain.

280

Compared to samples for human consumption, those for animal feeds were highly contaminated, with mean maximum levels of aflatoxins between 4 and 6 times greater $(100-250 \mu \mathrm{g} / \mathrm{kg})$. These results are consistent with those reported from Kenya for animal feed, 52-556 $\mu \mathrm{g} / \mathrm{kg}$, though as in this study, few samples (27 and 21 in the respective studies) were collected (Rodrigues, Handl, \& Binder, 2011). Similarly in Ethiopia, $26.2 \%$ of feed samples contained AFB1 at levels exceeding $100 \mu \mathrm{g} / \mathrm{kg}$ (Gizachew, Szonyi, Tegegne, Hanson, \& Grace, 2016). There is a linear correlation between AFB1 in feed consumed by dairy animals and AFM1 excreted in milk 284 (Golge, 2014), in which it remains stable following pasteurization and ultra-high temperature 285 286 treatments (Bilandžić et al., 2015). The detection of AFM1 in poultry products following consumption of aflatoxin-contaminated feed has negative implications for public (Iqbal, Nisar, 287 Asi, \& Jinap, 2014) and livestock health (Gündüz \& Oznurlu, 2014). So in spite of the small 288 sample size, these findings suggest that a greater awareness of the presence of aflatoxins in 289 animal feed in Rwanda is required, coupled with piloting and scaling of known and adapted 290 interventions to reduce risk of aflatoxin contamination. 
291 The percentage range of maize flour samples for human consumption above EC regulation 292 varied in our study, between 66-100\%; this is the most stringent limit for both AFB1 and total 293 aflatoxins, 2 and $4 \mu \mathrm{g} / \mathrm{kg}$ respectively (EC, 2006). However, 28-87\% of samples had higher 294 levels than the US FDA regulatory limit of $20 \mu \mathrm{g} / \mathrm{kg}$ for total aflatoxins (Luo et al., 2011). This 295 situation inevitably prejudices Rwandan products on international markets; cereal-based products have already been rejected at European borders for non-compliance (EU, 2015). Developed countries offer a lucrative and high-value export market and a source of income for developing countries. Failure to meet food safety standards is often related to limited resources and institutional constraints. Sanitary and Phytosanitary Standards (SPS) can vary but should be seen as non-tariff barriers (Li \& Beghin, 2012) that can help persuade exporting countries to upgrade quality standards not only to meet the requirements of their export markets but also food safety in their local markets (Jongwanich, 2009; Neeliah, Neeliah, \& Goburdhun, 2013).

303

304

While aflatoxin levels are notoriously difficult to fully characterize in a single study, given that they can change drastically depending on the harvest season, these results highlight challenges and opportunities to improve food safety in Rwanda. Further surveys and testing of interventions can help further characterize the dynamics and scope of this challenge in Rwanda, and resolve the best available options to address it. In parallel, ongoing regional and continental discussions, including the East African Community's recently developed Roadmap to address aflatoxin contamination outlines priorities and a range of interventions that have been effective elsewhere. Integration of appropriate Good Agricultural Practices, including proper tillage, fertilizer application (Tubajika, Mascagni, Damann, \& Russin, 1999; Mutiga et al., 2014), use of appropriate varieties (Bhatnagar-Mathur, Sunkara, Bhatnagar-Panwar, Waliyar, \& Sharma, 2015), proper harvesting (eg, not placing harvested maize on the soil), and proper drying and storage, can be effective at reducing aflatoxin levels in maize and other crops. Furthermore, biological control using Aflasafe is being piloted and scaled out in various sub-Saharan African countries, and could be considered for application in Rwanda (Bhatnagar-Mathur et al., 2015). The disparate amounts of maize above the limit for different official standards further highlights the need for a better understanding of what the appropriate level is in a Rwandan and subSaharan African context. While the spectre of aflatoxin contamination is a challenge to address, strategic adaptation and deployment of appropriate interventions can help secure a safe harvest. 


\section{Conclusion}

322 The percentage range above each limit considered vary between 66-100\%, 28-87\% and 2-35\%

323 for EU $(2 \mu \mathrm{g} / \mathrm{kg})$, Kenya-WFP $(10 \mu \mathrm{g} / \mathrm{kg})$ and USA FDA $(20 \mu \mathrm{g} / \mathrm{kg})$ limits, respectively while $32475 \%$ of animal feed samples had $>100 \mu \mathrm{g} / \mathrm{kg}$ AFB1, the FDA limit. All vendors declared that 325 they are unware of aflatoxins and their consequences. These findings reveal the need to both 326 enforce and update existing SPS relating aflatoxins in Rwanda, and for education programs to 327 raise awareness amongst stakeholders and their capacity to reduce aflatoxin risk. Consideration 328 should also be to more widespread testing of food products, e.g. milk and eggs that are likely to 329 be contaminated because of the widespread use of maize feed and the potential negative 330 consequences on public health. Follow up studies are necessary to more extensively assess the 331 scope and dynamics of aflatoxin contamination across multiple years, and to identify and deploy 332 effective and sustainable interventions.

\section{Acknowledgments}

334 This project was supported by the BecA-ILRI Hub through the Africa Biosciences Challenge 335 Fund $(\mathrm{ABCF})$ program. The ABCF Program is funded by the Australian Department for Foreign 336 Affairs and Trade (DFAT) through the BecA-CSIRO partnership; the Syngenta Foundation for

337 Sustainable Agriculture (SFSA); the Bill \& Melinda Gates Foundation (BMGF); the UK 338 Department for International Development (DFID) and; the Swedish International Development 339 Cooperation Agency (Sida). The authors are also thankful for the assistance provided by the 340 Laboratory of Analysis of Foods, Medicines, Water and Toxics (LADAMET) (University of 341 Rwanda); and for a discounted purchase price of testing kits from Helica Biosystems, Inc. 342 


\section{References}

Anitha, S., Raghunadharao, D., Waliyar, F., Sudini, H., Parveen, M., Rao, R., \& Kumar, P. L. (2014). The association between exposure to aflatoxin, mutation in TP53, infection with hepatitis B virus, and occurrence of liver disease in a selected population in Hyderabad, India. Mutation Research. Genetic Toxicology and Environmental Mutagenesis, 766, 23-8. http://doi.org/10.1016/j.mrgentox.2013.12.011

Asiki, G., Seeley, J., Srey, C., Baisley, K., Lightfoot, T., Archileo, K., ... Gong, Y. Y. (2014). A pilot study to evaluate aflatoxin exposure in a rural Ugandan population. Tropical Medicine and International Health, 19(5), 592-599. http://doi.org/10.1111/tmi.12283

Awadelkarim, K. D., Mariani-Costantini, R., \& Elwali, N. E. (2012). Cancer in the Sudan: An overview of the current status of knowledge on tumor patterns and risk factors. Science of the Total Environment, 423, 214-228. http://doi.org/10.1016/j.scitotenv.2010.09.010

Bhatnagar-Mathur, P., Sunkara, S., Bhatnagar-Panwar, M., Waliyar, F., \& Sharma, K. K. (2015). Biotechnological advances for combating Aspergillus flavus and aflatoxin contamination in crops. Plant Science, 234, 119-132. http://doi.org/10.1016/j.plantsci.2015.02.009

Bilandžić, N., Varenina, I., Kolanović, B. S., Božić, Đ., Đokić, M., Sedak, M., ... Cvetnić, Ž. (2015). Monitoring of aflatoxin M1 in raw milk during four seasons in Croatia. Food Control, 54, 331-337. http://doi.org/10.1016/j.foodcont.2015.02.015

Campbell, a. D., Whitaker, T. B., Pohland, a. E., Dickens, J. W., \& Park, D. L. (1986). Sampling, sample preparation, and sampling plans for foodstuffs for mycotoxin analysis. Pure and Applied Chemistry. http://doi.org/10.1351/pac198658020305

Chatikobo P, Manzi M, Kagarama J, Rwemarika J D \&Umunezero O 2009:Benchmark study on husbandry factors affecting reproductive performance of smallholder dairy cows in the Eastern Province of Rwanda. Livestock Research for Rural Development. Volume 21, Article \#83. Retrieved August 24, 2016, from http://www.lrrd.org/lrrd21/6/chat21083.htm

Clay D.C., Dejaegher Y.M.J.(1987). Agro-ecological zone: The development of a regional classification scheme for Rwanda. Tropicultura. 5,4 : 153 - 159 retrieved on February 9, 2015 from http://www.tropicultura.org/text/v5n4/153.pdf

D’Mello, J. P. F., Placinta, C. M., \& Macdonald, a. M. C. (1999). Fusarium mycotoxins: a review of global implications for animal health, welfare and productivity. Animal Feed Science and Technology, 80(3-4), 183-205. http://doi.org/10.1016/S0377-8401(99)00059-0

Doi, K., \& Uetsuka, K. (2014). Mechanisms of Mycotoxin-induced Dermal Toxicity and Tumorigenesis Through Oxidative Stress-related Pathways. Journal of Toxicologic Pathology, 27(1), 1-10. http://doi.org/10.1293/tox.2013-0062 
EC: European Commission: COMMISSION REGULATION (EC) No 1881/2006 of 19

December 2006 setting maximum levels for certain contaminants in foodstuffs( 2006). retrieved on November 11, 2014 from http://eurlex.europa.eu/LexUriServ/LexUriServ.do?uri=OJ:L:2006:364:0005:0024:EN:PDF

Elzupir, A. O., \& Alamer, A. S. (2014). Quantitative cancer risk of aflatoxin in peanut butter and vegetable oils: Sudan case study. Toxin Reviews, (0), 1-4

Ek, K., Ka, L., \& Kang, E. K. (2009). Aflatoxin B1 and M1 contamination of animal feeds and milk from urban centers in Kenya, 9(4).

EU (2015). Rapid alert system for food and feed retrieved on January 24 from https://webgate.ec.europa.eu/rasffwindow/portal/?event=SearchByKeyword $\&$ NewSearch $=1 \&$ Keywords=rwanda

FDA. 2016. U.S. Food and Drug Administration Guidelines for Aflatoxin Levels. Retrieved on May 12 from http://agriculture.mo.gov/plants/feed/aflatoxin.php

Francis A.R., Shetty T.K., \& Bhattacharya R.K.(1989). Modifying role of dietary factors on the mutagenicity of aflatoxin B1: in vitro effect of plant flavonoids. Mutation Research/Genetic Toxicology, 222 (4): 393-401

Gizachew, D., Szonyi, B., Tegegne, A., Hanson, J., \& Grace, D. (2016). Aflatoxin contamination of milk and dairy feeds in the Greater Addis Ababa milk shed, Ethiopia. Food Control, 59, 773-779. http://doi.org/10.1016/j.foodcont.2015.06.060

Golge, O. (2014). A survey on the occurrence of aflatoxin M1 in raw milk produced in Adana province of Turkey. Food Control, 45, 150-155. http://doi.org/10.1016/j.foodcont.2014.04.039

Gündüz, N., \& Oznurlu, Y. (2014). Adverse effects of aflatoxin B 1 on skeletal muscle development in broiler chickens. British Poultry Science, 55(March 2015), 684-692. http://doi.org/10.1080/00071668.2014.949621

Gnonlonfin G.J., Hell K., Adjovi Y., Fandohan P., Koudande D.O., Mensah G.A., Sanni A., \& Brimer L. (2013). A review on aflatoxin contamination and its implications in the developing world: a sub-Saharan African perspective. Critical Reviews in Food Science and Nutrition. 53(4):349-65. doi: 10.1080/10408398.2010.535718

International Agency for Research on Cancer. (2015). Mycotoxin control in low- and middleincome countries. Retrieved from http://www.ncbi.nlm.nih.gov/pubmed/27030861

IFPRI (2011). PRESS RELEASE : New Study Documents Spread of Aflatoxins in Kenya Scientists Discuss Findings with Policymakers at International Workshop retrieved on December 2014 from http://www.ifpri.org/pressrelease/new-study-documents-spreadaflatoxins-kenya 
Iqbal, S. Z., Nisar, S., Asi, M. R., \& Jinap, S. (2014). Natural incidence of aflatoxins, ochratoxin A and zearalenone in chicken meat and eggs. Food Control, 43, 98-103. http://doi.org/10.1016/j.foodcont.2014.02.046

Ismail, M., Taligoola, H., \& Ssebukyu, E. (2004). Mycobiota associated with maize grains in Uganda with special reference to aflatoxigenic Aspergilli. Journal of Tropical Microbiology and Biotechnology, 2(August 1999), 17-26. http://doi.org/10.4314/jtmb.v2i1.35420

Jolly, P., Jiang, Y., Ellis, W., Awuah, R., Nnedu, O., Phillips, T., ... Jolly, C. (2006). Determinants of aflatoxin levels in Ghanaians: Sociodemographic factors, knowledge of aflatoxin and food handling and consumption practices. International Journal of Hygiene and Environmental Health, 209, 345-358.http://doi.org/10.1016/j.ijheh.2006.02.002

Jolly, C. M., Bayard, B., Awuah, R. T., Fialor, S. C., \& Williams, J. T. (2009). Examining the structure of awareness and perceptions of groundnut aflatoxin among Ghanaian health and agricultural professionals and its influence on their actions. Journal of Socio-Economics, 38, 280-287. http://doi.org/10.1016/j.socec.2008.05.013

Jongwanich, J. (2009). Impact of food safety standards on processed food exports from developing countries. ADB Economics Working Paper Series, 154(5), 1-28. http://doi.org/10.1016/j.foodpol.2009.05.004

Kaaya, A. N., \& Kyamuhangire, W. (2006). The effect of storage time and agroecological zone on mould incidence and aflatoxin contamination of maize from traders in Uganda.

International Journal of Food Microbiology, 110, 217-223.

http://doi.org/10.1016/j.ijfoodmicro.2006.04.004

Kumar, G. D. S., \& Popat, M. N. (2010). Farmers' perceptions, knowledge and management of aflatoxins in groundnuts (Arachis hypogaea L.) in India. Crop Protection, 29(12), 15341541. http://doi.org/10.1016/j.cropro.2010.08.019

Lewis, L., Onsongo, M., Njapau, H., Schurz-Rogers, H., Luber, G., Kieszak, S., .. Rubin, C. (2005). Aflatoxin Contamination of Commercial Maize Products during an Outbreak of Acute Aflatoxicosis in Eastern and Central Kenya. Environmental Health Perspectives, 113(12), 1763-1767. http://doi.org/10.1289/ehp.7998

Li, Y., \& Beghin, J. C. (2012). A meta-analysis of estimates of the impact of technical barriers to trade. Journal of Policy Modeling, 34(3), 497-511.

http://doi.org/10.1016/j.jpolmod.2011.11.001

Lombard, M. J. (2014). Mycotoxin exposure and infant and young child growth in Africa: what do we know? Annals of Nutrition \& Metabolism, 64 Suppl 2, 42-52. http://doi.org/10.1159/000365126 
Luo, M., Brown, R. L., Chen, Z.-Y., Menkir, A., Yu, J., \& Bhatnagar, D. (2011). Transcriptional profiles uncover Aspergillus flavus-induced resistance in maize kernels. Toxins, 3(7), 76686. http://doi.org/10.3390/toxins3070766

Matumba, L., Sulyok, M., Njoroge, S. M. C., Njumbe Ediage, E., Van Poucke, C., De Saeger, S., \& Krska, R. (2014). Uncommon occurrence ratios of aflatoxin B1, B 2, G 1, and G 2 in maize and groundnuts from Malawi. Mycotoxin Research, 1. http://doi.org/10.1007/s12550014-0209-Z

Matumba, L., Van Poucke, C., Monjerezi, M., Njumbe Ediage, E., \& De Saeger, S. (2015). Concentrating aflatoxins on the domestic market through groundnut export: A focus on Malawian groundnut value and supply chain. Food Control, 51, 236239. http://doi.org/10.1016/j.foodcont.2014.11.035

Minecofin (2014). Economic Development and Poverty Reduction Strategy 2013 - 2018 retrieved on February 23, 2014 from http://www.minecofin.gov.rw/fileadmin/General/EDPRS_2/EDPRS_2_FINAL1.pdf

Maestroni, B., \& Cannavan, A. (2011). Determining Mycotoxins and Mycotoxigenic Fungi in Food and Feed. Determining Mycotoxins and Mycotoxigenic Fungi in Food and Feed. Elsevier. http://doi.org/10.1533/9780857090973.1.3

Muthomi, J. W., Mureithi, B. K., Chemining, G. N., Gathumbi, J. K., \& Mutit, E. W. (2012). Aspergillus species and Aflatoxin b 1 in soil, maize grain and flour samples from semi-arid and humid regions of Kenya, 2(January), 22-34.

Mutiga, S. K., Were, V., Hoffmann, V., Harvey, J. W., Milgroom, M. G., \& Nelson, R. J. (2014). Extent and drivers of mycotoxin contamination: inferences from a survey of kenyan maize mills. Phytopathology, 104(11), 1221-1231. http://doi.org/10.1094/PHYTO-01-14-0006-R

Mwihia, J. T., Straetmans, M., Ibrahim, a., Njau, J., Muhenje, O., Guracha, a., ... Lewis, L. (2008). Aflatoxin levels in locally grown maize from Makueni District, Kenya. East African Medical Journal, 85(7), 311-317. http://doi.org/10.4314/eamj.v85i7.9648

Ndung, J. W., Makokha, a O., Onyango, C. a, Mutegi, C. K., Wagacha, J. M., \& Christie, M. E. (2013). Prevalence and potential for aflatoxin contamination in groundnuts and peanut butter from farmers and traders in Nairobi and Nyanza provinces of Kenya, Journal of Applied Biosciences, 4922-4934.

Neeliah, S. a., Neeliah, H., \& Goburdhun, D. (2013). Assessing the relevance of EU SPS measures to the food export sector: Evidence from a developing agro-food exporting country. Food Policy, 41, 53-62. http://doi.org/10.1016/j.foodpol.2013.04.002

Odeyemi T.J. (2003). Philosophy of adult education and the implication for agricultural extension service. Journal of Agriculture and Social Research. 3: 55-63.. http://dx.doi.org/10.4314/jasr.v3i2.2794 
Owaga, E., Muga, R., Mumbo, H., \& Aila, F. (2011). Chronic dietary aflatoxins exposure in Kenya and emerging public health concerns of impaired growth and immune suppression in children, 5(June), 1325-1336.

Peers, F. G., \& Linsell, C. a. (1973). Dietary aflatoxins and liver cancer--a population based study in Kenya. British Journal of Cancer, 27, 473-484. http://doi.org/10.1038/bjc.1973.60

Perrone, G., Gallo, A., \& Logrieco, A. F. (2014). Biodiversity of Aspergillus section Flavi in Europe in relation to the management of aflatoxin risk. Frontiers in Microbiology, 5(July), 377. http://doi.org/10.3389/fmicb.2014.00377

Pitt, J.I. (2014). Mycotoxins: Aflatoxins. Encyclopedia of Food Safety, 2(c), 289-294. http://doi.org/10.1016/B978-0-12-378612-8.00190-6

Prandini, a., Tansini, G., Sigolo, S., Filippi, L., Laporta, M., \& Piva, G. (2009). On the occurrence of aflatoxin M1 in milk and dairy products. Food and Chemical Toxicology, 47(5), 984-991. http://doi.org/10.1016/j.fct.2007.10.005

Probst C., Bandyopadhyay R. , \& Cotty P.J. (2014). Diversity of aflatoxin-producing fungi and their impact on food safety in sub-Saharan Africa. International Journal of Food Microbiology,174,113-122

Release, F. I., \& Foundation, M. G. (2011). Press release. Group, 1(202).

Rodrigues, I., Handl, J., \& Binder, E. M. (2011). Mycotoxin occurrence in commodities, feeds and feed ingredients sourced in the Middle East and Africa. Food Additives and Contaminants: Part B, 4(3), 168-179. http://doi.org/10.1080/19393210.2011.589034

Rushunju, G. B., Laswai, H. S., Ngowi, H. A., \& Katalambula, L. K. (n.d.). Aflatoxin contamination of locally- processed cereal-based complementary foods in Tanzania.

Sabran, Redzwan, M., Jamaluddin, Rosita, Mutalib, A., Sokhini, M., ... Aqilah, N. (2012). Socio-demographic and socio-economic determinants of adults' knowledge on fungal and aflatoxin contamination in the diets. Asian Pacific Journal of Tropical Biomedicine, 2(3), S1835-S1841. http://doi.org/10.1016/S2221-1691(12)60504-8

Tubajika, K. M., Mascagni, H. J., Damann, K. E., \& Russin, J. S. (1999). Nitrogen fertilizer influence on aflatoxin contamination of corn in Louisiana. Journal of Agricultural and Food Chemistry, 47(12), 5257-5260. http://doi.org/10.1021/jf990535f

Villers, P. (2014). Aflatoxins and safe storage. Frontiers in Microbiology, 5(APR), 1-6. http://doi.org/10.3389/fmicb.2014.00158

Wagacha, J. M., \& Muthomi, J. W. (2008). Mycotoxin problem in Africa: Current status, implications to food safety and health and possible management strategies. International Journal of Food Microbiology, 124, 1-12. http://doi.org/10.1016/j.ijfoodmicro.2008.01.008 
Zain, M. E. (2011). Impact of mycotoxins on humans and animals. Journal of Saudi Chemical Society, 15(2), 129-144. http://doi.org/10.1016/j.jscs.2010.06.006 


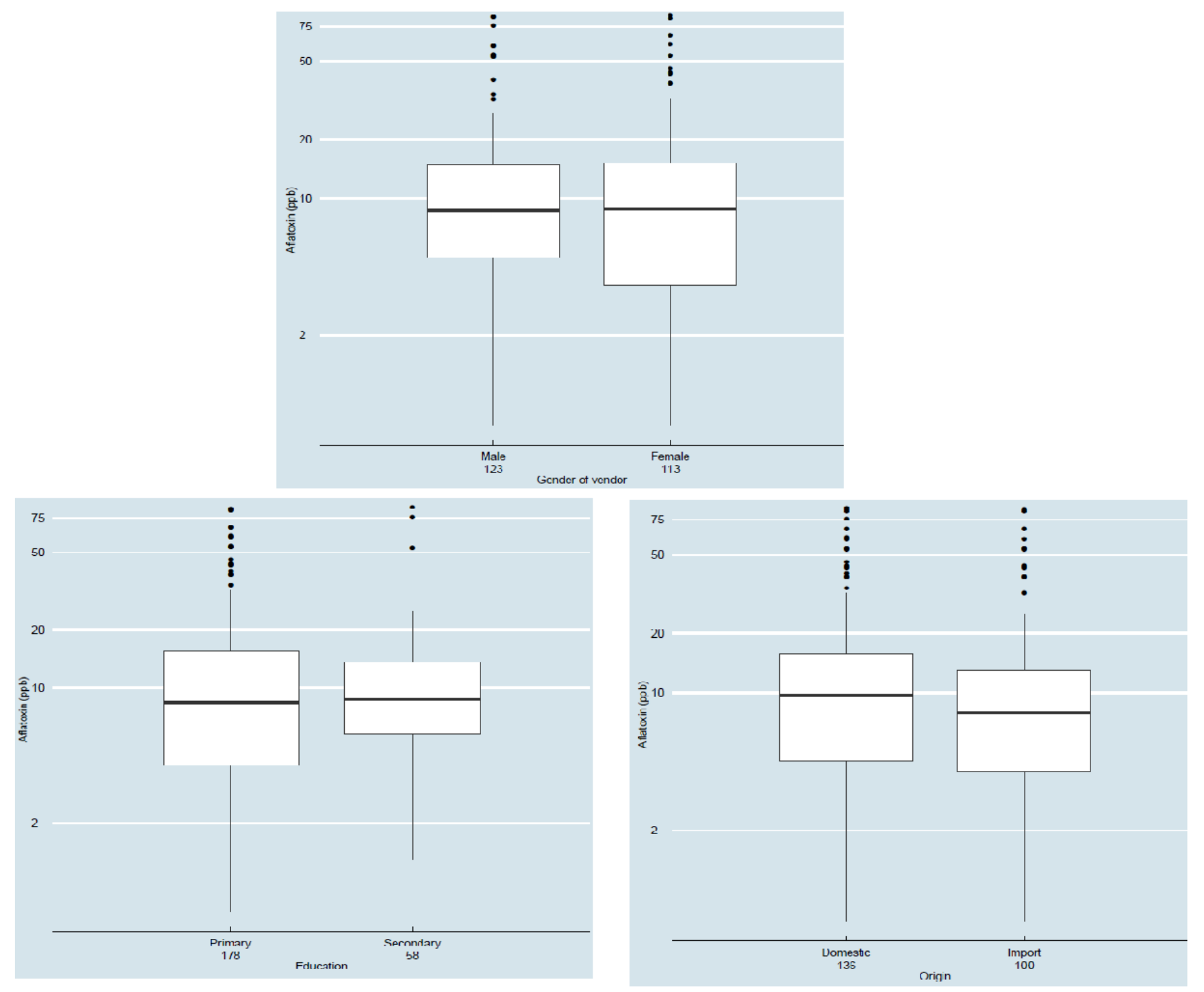

Figure 1 a, b,c: "The relationship between aflatoxin level and gender (a), level of education (b) and origin of flour (c). 


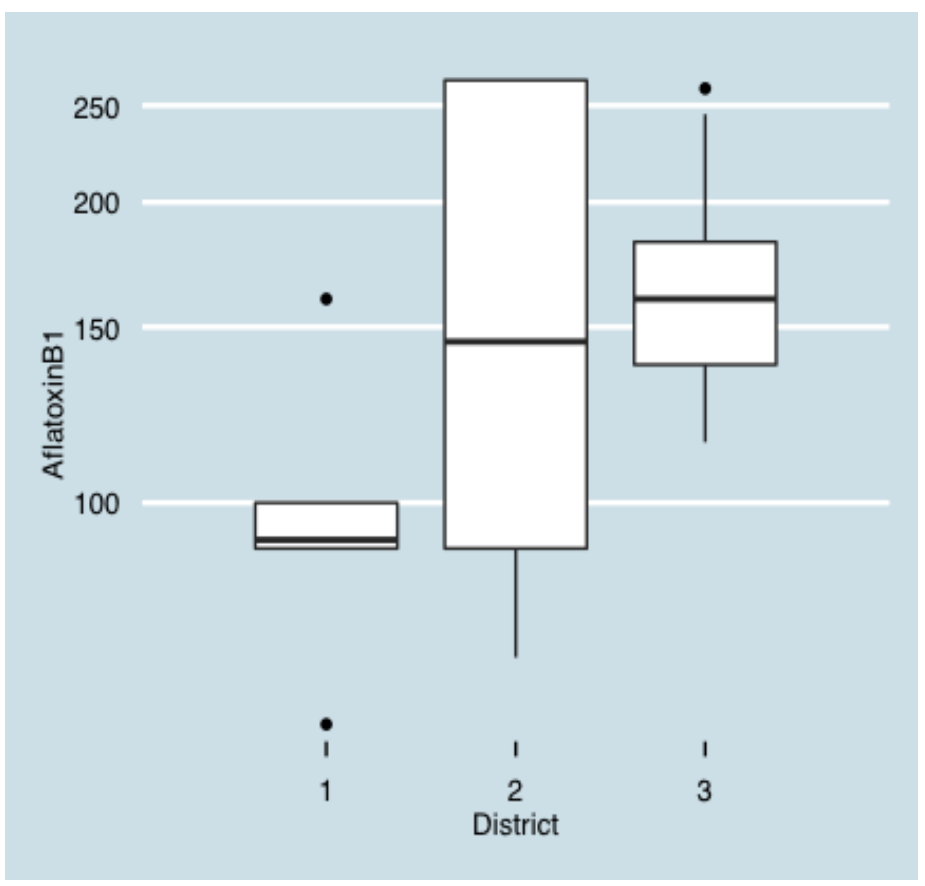

Figure 2: Aflatoxin levels in maize-based animal feed blends in three districts: Gasabo (1), Kicukiro (2) and Nyarugenge (3).

Table 1: ANOVA table showing contribution to variation in AFB1 by each socio-demographic factor during the first round

\begin{tabular}{lccccc}
\hline Socio-demographic factor & Df & $\begin{array}{c}\text { Sum } \\
\text { Squares(SS) }\end{array}$ & $\begin{array}{c}\text { Mean } \\
\text { Squares } \\
\text { (MQ) }\end{array}$ & $\begin{array}{c}\text { F } \\
\text { value }\end{array}$ & $\begin{array}{c}\text { Contribution } \\
\text { SS }(\%)\end{array}$ \\
\hline Market & 6 & 3.681 & 0.6135 & 7.5317 & 99.24776 \\
\hline Origin of maize & 1 & 0.0056 & 0.00563 & 0.0691 & 0.150988 \\
\hline Gender of vendors & 1 & 0.0059 & 0.00592 & 0.0727 & 0.159077 \\
\hline Education level of vendors & 1 & 0.0164 & 0.0164 & 0.2014 & 0.44218 \\
\hline Total & & & & & \\
\hline
\end{tabular}


Table 2: Variance components and market differences analysis

\begin{tabular}{lccccc}
\hline & Df & $\begin{array}{c}\text { Sums } \\
\text { squares } \\
\text { (SS) }\end{array}$ & $\begin{array}{c}\text { Mean } \\
\text { squares } \\
\text { (MQ) }\end{array}$ & F value & \% SS \\
\hline Market & 6 & 2.424 & 0.404 & 5.544 & 0.455 \\
\hline Round & 1 & 0.481 & 0.481 & 6.595 & 0.090 \\
\hline Market-Round & 6 & 2.422 & 0.404 & 5.539 & 0.455 \\
\hline total & & 5.327 & 1.288 & & \\
\hline
\end{tabular}


Table 3: Analysis of aflatoxin levels in maize intended for human consumption, by market across the two collections.

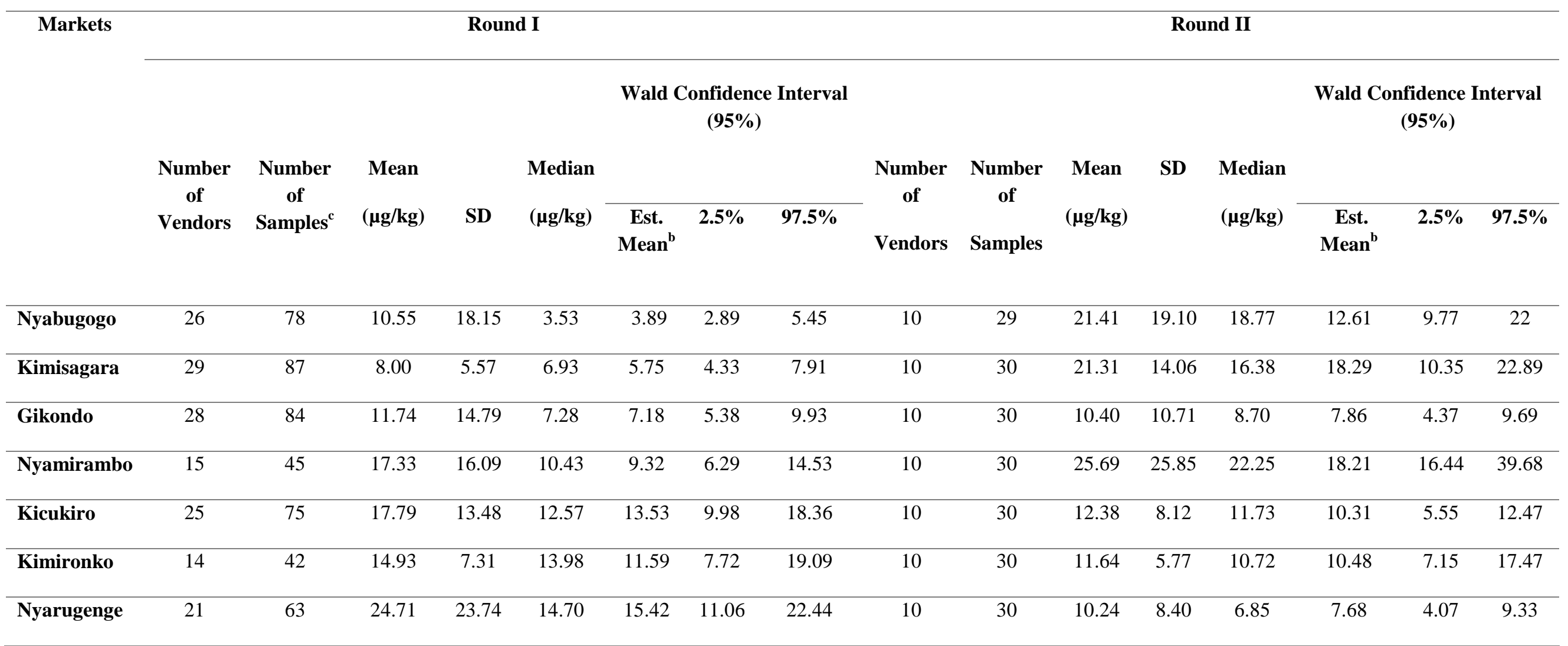

\section{${ }^{\mathrm{a}} \mathrm{SD}$ : Standard Deviation}

${ }^{\mathrm{b}}$ Est. Mean: Estimated Mean 
Table 4: Proportion of maize flour (food) samples above the European Union, Kenya-WFP and USA FDA regulations by collection round, and probability (based on chi-square test) that the relative proportions in affected maize among the markets between rounds 1 and 2 and the

\begin{tabular}{|c|c|c|c|c|c|c|}
\hline \multirow[t]{2}{*}{ Markets } & \multicolumn{2}{|c|}{$>2 \mu \mathrm{g} / \mathrm{kg}$} & \multicolumn{2}{|c|}{$>10 \mu \mathrm{g} / \mathrm{kg}$} & \multicolumn{2}{|c|}{$>20 \mu \mathrm{g} / \mathrm{kg}$} \\
\hline & $\begin{array}{c}\text { Round I } \\
(\%)\end{array}$ & $\begin{array}{c}\text { Round II } \\
(\%)\end{array}$ & $\begin{array}{c}\text { Round I } \\
(\%)\end{array}$ & $\begin{array}{c}\text { Round II } \\
(\%)\end{array}$ & $\begin{array}{c}\text { Round I } \\
(\%)\end{array}$ & $\begin{array}{c}\text { Round II } \\
(\%)\end{array}$ \\
\hline Nyabugogo & 66.7 & 89.7 & 28.2 & 62.1 & 10.3 & 34.5 \\
\hline Kimisagara & 85.1 & 100 & 28.7 & 86.7 & 2.3 & 23.3 \\
\hline Gikondo & 89.3 & 96.7 & 33.3 & 30 & 8.3 & 6.7 \\
\hline Nyamirambo & 91.1 & 100 & 37.8 & 80 & 24.4 & 30 \\
\hline Kicukiro & 100 & 96.7 & 62.7 & 63.3 & 21.3 & 6.7 \\
\hline Kimironko & 97.6 & 100 & 59.5 & 53.3 & 19 & 6.7 \\
\hline Nyarugenge & 98.4 & 96.7 & 79.4 & 30 & 30.2 & 10 \\
\hline $\begin{array}{l}\text { Percentage range } \\
\text { above each limit }\end{array}$ & $66-$ & 100 & & & & 35 \\
\hline
\end{tabular}

\section{P-Value (Chi-square)}

\begin{tabular}{lccr}
\hline Market & $<0.0001$ & $<0.0001$ & 0.0008 \\
\hline Round & $<0.0001$ & 0.002 & 0.589 \\
\hline $\begin{array}{l}\text { Market X } \\
\text { Round }\end{array}$ & 0.0926 & $<0.0001$ & $<0.0001$ \\
& & &
\end{tabular}

interaction of round and market. 